\title{
THE PRINCIPLE OF JUSTICE IN TRANSACTIONS BASED ON PROFIT AND LOSS SHARING IN SHARIA BANKS*
}

\author{
Trisadini Prasastinah Usanti, ${ }^{* *}$ A. Shomad, ${ }^{* * *}$ and Ari Kurniawan ${ }^{* * * *}$ \\ Private Law Department, Faculty of Law Airlangga University, Surabaya \\ Jalan Darmawangsa Dalam Selatan, Surabaya, Jawa Timur 60286
}

\begin{abstract}
In fund raising with mudharabah agreement only contain a clause about sharing profits alone, does not contain a clause about sharing losses because the losses in case the fund will be borne by LPS, and there is no clause about profit sharing or revenue sharing is used. At mudharabah and musharakah financing contain a clause on sharing profits and losses, although there is a clause that does not reflect justice.
\end{abstract}

Keywords: sharia bank, profit sharing, justice.

\section{Intisari}

Dalam penghimpunan dana dengan perjanjian mudharabah hanya memuat klausul tentang berbagi keuntungan saja, tidak memuat klausul tentang berbagi kerugian karena apabila terjadi kerugian maka dana tersebut akan ditanggung oleh LPS, dan tidak ada klausul tentang profit sharing atau revenue sharing yang dipergunakan. Pada pembiayaan mudharabah dan pembiayaan musyarakah memuat klausul tentang berbagi keuntungan dan kerugian, meskipun masih ada klausul yang belum mencerminkan keadilan.

Kata kunci: bank syariah, bagi hasil, keadilan.

\section{Pokok Muatan}

A. Background 309

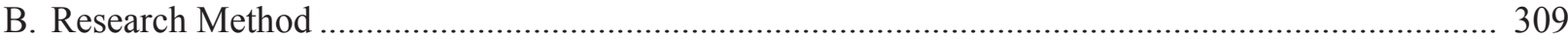

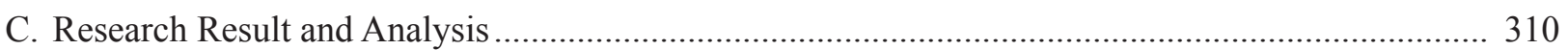

1. Principle of Justice in Transactions Based on Profit and Loss Sharing ....................................... 310

2. Application of the Principle of Justice in Funds Collection Based on Profit and Loss Sharing . 311

3. The Application of Principle of Justice in Financing Based on Profit and Loss Sharing............. 315

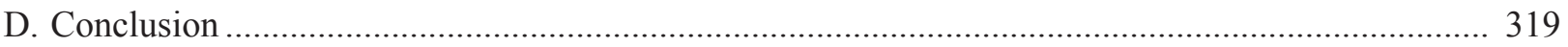

\footnotetext{
The results of leading research universities funded by college operational assistance fund (BOPTN) 2013.

Alamat korespondensi: aditris@ymail.com

*** Alamat korespondensi: sishomad@yahoo.co.id

**** Alamat korespondensi: arieeee 1101@yahoo.com
} 


\section{A. Background}

The main function of sharia bank is to act as an intermediary institution in addition to its social function. Sharia bank collects funds through savings or investment. Such savings can be in the form of wadiah deposit and current account (gyro), while investment is in the form of mudharabah saving and deposit in addition to channeling funds in the form of financing. Financing is a form of funding granted by one party to another party to support the planned investment, either by themselves or an established institution. In other words, the financing is a funding issued to support the planned investment. ${ }^{1}$

The form of fund distribution intended for investment purposes in Islamic banking can be done by profit and loss sharing agreement and can be generally divided into two kinds, namely mudharabah and musharakah. Profit and loss sharing agreement, known as Profit and Loss Sharing Principle (PLS), is one type of agreement used by Islamic banking in its products. Almudharabah is an agreement made by the sharia banks and customers, and in terms of funds disbursement, sharia banks act as the owner of the funds (shahibul maal), while the customers act as the fund manager (mudharib). In collecting funds, sharia banks act as the fund manager (mudharib), while the customers act as the owner of the funds (shahibul maal), by investing in sharia banks through savings or through mudharabah deposits. Al-musharakah is a partnership agreement between two or more parties to a certain business, each of which party contributes funds or expertise with the agreement that the benefits and risks will be shared in accordance with the agreement, in musharakah financing practices applied by sharia banks in activities distribution of funds.

Mudharabah is an investment of fund (shahibul maal) to fund managers (mudharib) to conduct certain business activities, by using the method of profit and loss sharing or method of net revenue sharing between the two parties based on the agreed ratio. ${ }^{2}$ Such profit and loss sharing application in the transactions carried out by the sharia banks has created justice between the parties to a transaction. This statement is confirmed in a general explanation of Sharia Banking Act that says:

[...] sharia principles are based on the values of justice, expediency, balance, and universality (rahmatan lil 'alamin). These values are applied in banking regulations that are based on the principle of the so-called Sharia Banking. Principles of Sharia Banking are part of the teachings of Islam with regard to the economy. One of the principles of Islamic economics is a prohibition of riba in its various forms, and instead using systems such as profit and loss sharing. With the principle of profit and loss sharing, Sharia Bank can create a healthy and fair investment climate because all parties are able to share both the advantages and potential risks that arise, thus creating impartial position between the bank and its customers.

Based on the above, the issue examined in this study is whether the principle of justice has been applied in collection and distribution of funds based on profit and loss sharing.

\section{B. Research Method}

Legal research is conducted by a method according to the distinctive character of legal science. The hallmark of the science of law is its normative nature. ${ }^{3}$ This study is a follow-up that had previously been done on the absorption of Islamic law in the agreement in X and Y Sharia Banks. This study is to examine the application of the principle of justice in the collection and distribution of funds based on profit and loss sharing. Materials used are laws covering supra, primary and secondary legal materials, and are supported by the results of interviews with the staff of $\mathrm{X}$ and $\mathrm{Y}$ Sharia

Muhamad, 2005, Manajemen Pembiayaan Bank Syariah, Unit Penerbit dan Percetakan (UPP) AMP YKPN, Yogyakarta, p. 17.

Bank Indonesia Regulation Nomor 8/21/PBI/2006 dated October $5^{\text {th }} 2006$ regarding Asset Quality Rating for Commercial Banks Conducting Business Based on Sharia Principles, Article 1 paragraph (5).

Philipus M.Hadjon and Tatiek Sri Djatmiati, 2005, Argumentasi Hukum, Gadjah Mada University Press, Yogyakarta, p. 1. 
Banks. The materials are then analyzed and further described in descriptive narrative form.

\section{Research Result and Analysis}

1. Principle of Justice in Transactions Based on Profit and Loss Sharing

Discussions on issues of justice have never stopped since ancient times until today, because the issue of justice is very essential in human life. Justice is one of the goals of every religion in the world, including the Islamic religion which puts justice at a very important place in the life of the nation. ${ }^{4}$ Islamic Law Encyclopedia states that etymologically, the meaning of fair ( $a l$ - 'adl) means impartial or does not equate with anything else (almusawah). Other terms of the al- 'adl is al-qist, al-misl which mean "the same as" or "such as". Meanwhile, the meaning of fair, terminologically, is to equate something in its place (wad-'asy-syaifi muqamih). According to Ibn Qudamah (he is an expert in Hambali school of Islamic law), justice is something that is hidden, motivated solely due to fear of Allah SWT. Justice is strongly associated with rights and obligations. Those rights and obligations are associated with mandate, while the mandate must be given to those who deserve it. ${ }^{5}$

The principle of justice is one of the fundamental characteristic of the three characteristics of the sharia economic and banking system, in addition to avoiding prohibited activities and paying attention to aspects of expediency. The principle of justice requires and teaches four terms in the management of sharia banks, namely: ${ }^{6}$ (1) transparency and honesty; (2) fair transactions; (3) healthy competition; and (4) mutually beneficial agreement. In the view of philosophy, the ultimate goal of the law is justice, in relation to Islamic law that justice must be achieved by referring to the basic guidelines of Islam, the Holy Quran and the
Hadith, meaning that the goal of justice through the legal system must be started from the two sides and lead to two-sided fairness too. The purpose of the two-sided justice is the ultimate goal of justice to be achieved by a universal legal system oriented towards justice among human beings and to Allah. Justice among humans may not differ in interpreting legal justice. While the justice that leads to Allah is that all activities performed by humans must be within the remit of worship to Him. This opinion is in line with Friedmann's opinion that "as long as the principle of fairness standard is not adhered to the religion then such guideline will not reach the ideal point of the principle of justice". The cue of legal justice willed by Allah is contained in: ${ }^{7}$

O people who believe, you shall be those who always uphold the truth as God, bearing witness with justice. And let not your hatred against a people, you tend to make unfair. Validity is unfair, because the fair it is closer to piety. And fear Allah, surely Allah is Aware of what you do. (Al Maidah (5): (8)).

One of the underlying principles of sharia agreement is the principle of Al-Adalah (justice). The implementation of this principle in an agreement or contract requires the parties to do what is right in expressing the will and circumstances, meeting all its obligations. Agreements must always be profitably fair and balanced, and must not cause harm to either party. ${ }^{8}$ The parties conducting agreement drafting shall adhere to the principle of justice. It is a principle that puts all the rights and obligations based on the principle of syara' legal truth, therefore by doing justice, one would not do unjust toward others.

In sharia banking conducted by both the sharia banks and the sharia business units in Indonesia during January 2013, mudharabah financing amounted to 12.027 billion, and musharakah amounted to 28.092 billion, much

\footnotetext{
Abdul Manan, 2006, Reformasi Hukum Islam di Indonesia, Raja Grafindo Persada, Jakarta, p.111.

Ibid., p. 112.

Agustianto, "Prinsip Syariah dalam Ekonomi dan Perbankan", http://www.agustiantocentre.com/?p=345, accessed on June $21^{\text {st }} 2013$.

Abdul Ghofur Anshori, 2006a, Filsafat Hukum, Gadjah Mada University Press, Yogyakarta, p. 64.

Abdul Ghofur Anshori, 2006b, Pokok-Pokok Hukum Perjanjian Islam di Indonesia, Citra Media, Yogyakarta, p. 27.
} 
smaller than the murabahah financing which amounted to 89.665 billion in Rupiah. ${ }^{9}$ This is due to sale-based financing, particularly murabahah financing, is easy to be applied by sharia banks, given the level of benefits to be received by the sharia bank is certain, whereas the level of benefits in mudharabah and musharakah financings are uncertain, and the detailed calculations are needed to determine profit share based on the profit and loss sharing ratio between sharia banks and customers. In addition, there is the risk of moral hazard from mudharib (fund manager).

In mudharabah investment, the nature and spirit of togetherness and justice will become evident. This is seen through the togetherness in bearing losses in the project and sharing the profits swelling at the time of booming economy. ${ }^{10}$ On savings and deposits, mudharabah muthlaqah agreement is generally applicable, which is a form of cooperation between shahibul maal (depositor/ investor customers) and mudharib (Islamic banks) that is very broad and not limited by the specification of type, time and area of business. In financing, mudharabah muqayyada is applied, which is a form of cooperation between shahibul maal (sharia banks) and mudharib (depositor/ investor customers) whose scope is limited by the specifications of the type, time and area of business.

\section{Application of The Principle of Justice in} Funds Collection Based on Profit and Loss Sharing

Collection of funds according to Sharia Banking Act includes the form of savings and investment. Forms of savings are based on wadiah agreement for savings and current accounts, while investments are funds entrusted by clients to sharia banks and/or sharia business units based on mudharabah agreement or other agreements that do not conflict with Sharia principles in the form of deposits, savings, or other equivalent form with it. Meanwhile, investor customers are the people who put their money in sharia banks and/or sharia business units in the form of investment based on the agreement between the Sharia Bank or Sharia Business Units and the Customer. Savings are based on wadiah agreement or investment of funds based on mudharabah agreement or other agreements that do not conflict with sharia principles which may only be withdrawn under certain terms and conditions agreed upon, but it cannot be withdrawn by check, gyro, and/or other equivalent tools. Deposits ${ }^{11}$ are investment funds based on mudharabah agreement or other agreements that is not in conflict with Sharia principles which can be withdrawn only at a specific time based on the agreement between the Depositor and the Sharia Bank and/or Sharia Business Units. Gyro is a saving based on wadiah agreement or other agreements that do not conflict with Sharia principles, which may be withdrawn at any time by check, gyro, other forms of payment, or through overbooking. The discussion in this study is focused on investment in the form of savings and deposits based on mudharabah agreement.

Based on the analysis of a sample of mudharabah deposit agreements of X sharia bank, then the clause contained in the agreement is in accordance with the terms and conditions set forth in DSN Fatwa Number 03/DSN/DSN-MUI/IV/2000 on deposits and Number 15/DSN-MUI/IX/2000 on the Principles of Business Results Distribution in Sharia Financial Institution though not entirely, as described as follows: Firstly, legal relationship as outlined in the mudharabah agreement between the client as shahibul maal (fund owner) and sharia bank as mudharib (fund manager). Secondly, mudharabah deposit agreement number 2, a provision states that "CUSTOMER bears the investment risk and gives approval/permission

Bank Indonesia, "Financing Data from Sharia Banking", http://www.bi.go.id, accessed on May $28^{\text {th }} 2013$

Abd. Shomad, “Akad Mudharabah dalam Perbankan Syariah”, Yuridika, Vol. 16, No. 4, July-August 2001, p. 371.

According to Article 1 paragraph 7 of Banking Act, characteristic of the deposits are the ones that can be withdrawn only at a specific time based on the agreement with the bank depositors. Therefore, the right type of agreement to frame the product of the deposit is mudharabah, not wadiah, because the purpose of the mudharabah is to invest, and such capital will generate profit if the fund is managed in a certain time so it is more accurate to use mudharabah, that customers will get the advantage if the funds are managed by sharia banks beforehand. 
to the BANK to manage the funds invested in the BANK, and to be used and taken advantage of by BANKS in accordance with the principle of mudharabah muthlaqah without any limitation and is used in accordance with the principles of Sharia". This provision is in accordance with the character of mudharabah that if there is a loss that is not caused by the negligence of mudharib, then the bearer is the shahibul maal. Characters of mudharabah deposits in general are not mudharabah muthlaqah, not mudharabah muqqayadah. This is because the embodiment of the principle of prudence in managing funds of sharia banks then mudharabah agreement is mudharabah muthlaqah, which agreement is without limitation of time and place. This is to facilitate sharia banks in disbursing funds. In raising funds based on mudharabah agreement, it should be included in the agreement a clause stating that customer (shahibul maal) bears the risk of loss in the event of a loss that is not caused by mudharib, in this case is the sharia bank, given the characteristics of mudharabah agreement that shahibul maal bears capital loss if such loss is not caused by mudharib. However, in general, the funds collection agreements in sharia banks do not include the clause, because if there is a loss on sharia bank as the mudharib in fault or not, the Deposit Insurance Agency (LPS) will ensure customer refund amounted 2 billion Rupiah at maximum. This avoids customers from acknowledging transactions based on profit and loss sharing.

Thirdly, with regard to profit in mudharabah deposits, mudharib party should not betoken advantage for sure, but it should be agreed that the division of profit must be expressed in the form of a ratio. This provision is already contained in the provisions number 3, that "CUSTOMER and BANK agree to share the results of the fund invested by CUSTOMER by comparison to profit and loss sharing of $\mathrm{x} \%$ (x percent) for CUSTOMER and at $\mathrm{x} \%$ ( $\mathrm{x}$ percent) for BANK in a period as stated in the Deposit Advice above, which will be distributed/calculated and recorded on a monthly basis, provided that the results are valid up to a change in the agreed profit and loss sharing ratio between the BANK and the CUSTOMER".

Fourthly, in the sense of the advantage provided by sharia banks is depended on the business of sharia banks in managing the fund, if the results obtained from the management of the fund generate big profits, then the profits will be distributed to customers, as well as when the benefits obtained are declining, the decline will be covered as well by shahibul maal. Therefore, the application of mudharabah puts more emphasis on justice between the mudharib and shahibul maal. However, the agreement does not mention sharing system that is used in determining the distribution of the results of operations as set forth in DSN Fatwa Number 15/DSN-MUI/IX/2000 on the Principles of Business Results Distribution in Sharia Financial Institution. Fifthly, according to DSN Fatwa, the capital must be stated with the amount, in cash and not receivable. This is in accordance with the contract of mudharabah deposits in the Deposit Advice No. XXX.

In the example of mudharabah deposit agreement on Y sharia bank, the clause contained in the agreement has not yet fully meet the terms and conditions set forth in Number 03/DSN-MUI/ IV/2000 on deposits and Number 15/DSN-MUI/ IX/2000 on the Principles of Business Results Distribution in Sharia Financial Institution, namely:

a) It should be explicitly stated in the agreement that the legal relationship between the customer as shahibul maal (fund owner) and sharia bank as mudharib (fund manager). However, the agreement just mentions between the first and second parties.

b) It does not contain a clause about parties bearing the risk for loss of fund management. Given the underlying agreement is an agreement of mudharabah, the party bearing the risk of loss is shahibul maal (customer) unless the loss is caused by negligence of mudharib. In raising funds based on mudharabah agreement, the agreement should contain a clause about the customer (shahibul maal) 
bearing the risk of loss in the event of a loss that is not caused by mudharib, in this case is the sharia bank, given the characteristics of mudharabah agreement that shahibul maal bears capital loss if it is not caused by mudharib.

c) Characters of mudharabah deposits in general are not mudharabah muthlaqa, not mudharabah muqqayadah. This is because the embodiment of the principle of prudence in managing funds of sharia banks then mudharabah agreement is mudharabah muthlaqah, which agreement is without limitation of time and place. This is to facilitate sharia banks in disbursing funds. However, in the exemplary deposit agreement in Y Sharia Bank, it does not explicitly mention that the contract is mudharabah muthlaqah although the profile of Y Sharia Bank products mentions that the mudharabah agreement framing deposit products is mudharabah muthlaqah.

d) In relation with profits in mudharabah deposits, mudharib should not betoken fixed profit, but it is agreed that the division of profit must be expressed in the form of a ratio. This provision has been stipulated in the agreement mentioned above that "The portion of the profit and loss sharing ratio is $\mathrm{x} \%$ for the first Party and $\mathrm{x} \%$ for the second Party". In the sense of the profit provided by sharia banks depends on the business of sharia banks in managing the fund, if the revenue obtained from the management of the fund generates big profits, then the profits will be distributed to customers, as well as when the benefits obtained are declining, the decline will be covered as well by shahibul maal. Therefore, the application of mudharabah puts more emphasis on justice between shahibul maal and mudharib. e) The agreement does not mention the sharing system used in determining the distribution of the revenue of business as set forth in DSN Fatwa Number 15 /DSN-MUI/IX/2000 on the Principles of Business Results Distribution in Sharia Financial Institution.

f) According to a DSN Fatwa, a capital must be stated with the amount, in cash and not receivable. The agreement does not explicitly state how much the amount of capital invested in the form of mudharabah deposit is.

If compared with conventional bank deposits that set profits with interest, which according to sharia is included in the category of riba, disclaimer of interest considered as riba raises questions about what can replace the application of the interest rate mechanism in the framework of sharia banking. If the interest payments and withdrawals are prohibited, how do sharia banks operate? Here is where PLS comes in, replacing the system of interest with profit and loss sharing system as a method of resource allocation, although there are many types of agreement in Islamic financing, but there are some important types of transactions: mudharabah (fund agreements), musharakah (partnership agreements); and mark-up method (raising prices). ${ }^{12}$ This theory states that sharia banks will provide financing sources (financial) wide to the borrower (debtor) based on the risk (either in relation to profits and losses) are different from the financing interest in the world of conventional banking system that all risks are borne by the borrower (debtor). ${ }^{13}$ Indeed, in the system of interest and profit and loss sharing have a similarity that is equally beneficial to the owners of funds, but both have a difference in principle. The main difference is the interest money system that is forbidden by Islam, while the profit and loss sharing is basically non-profit so it is not riba, therefore not forbidden in the teachings of Islam. ${ }^{14}$ Interest

13 Edward Elgar, Mervyn Lewis and Latifa Algaoud, 2001, Perbankan Syariah (Trans. Burhan Wirasubrata), Serambi Ilmu Semesta, Jakarta, p. 13.

14 Abdullah Saeed, 1996, Islamic Banking and Interest a Study of The Prohibition of Riba and Contemporary Interpretation, E.J Briil, LeidenNew York-Koln, p. 90. 
determination is made at the time the agreement takes place under the assumption that it should always be profitable, no loss assumption, interest payment must always be done without considering that the project executed produces a profit or not. While the system for determining the ratio of profit and loss sharing at the time the agreement is made with reference to the possibility of profit and loss. Therefore, in a project carried out by the customer, the losses will be shared. ${ }^{15}$ Hence also, the sharia banking was designed to establish relationship in bearing the risk of business and sharing the results of business between the client (owner of fund/shahibul maal) who save their money in sharia banks as the fund manager (mudharib) of the society and intersharia banks as the owner of fund (shahibul maal) with customers who manage the fund (mudharib).

In conventional deposits, the deposit owners can ensure that they will be receiving interest and they are exposed to less risk due to the acquisition of relatively definite and fixed interest. Apparent injustice is seen in such transaction. When bank receives abundant benefits, then such advantage will only be enjoyed by the bank, as the bank only gives the pre-defined interest, and vice versa if the bank experiences a decline in profits or even if the condition is not profitable at all, the bank must provide benefits in accordance with a pre-defined rate. From this description, it appears that there is an imbalance in the relationship. Unlike the case in investing activities in the mudharabah deposit agreement and mudharabah saving, the benefit to be received is always uncertain, as the ratio is set only for the result. For example, the calculation of mudharabah deposit in Islamic banks: ${ }^{16}$

A has a deposit amounting to Rp 10.000.000, one-month period (December $1^{\text {st }}$ until January $1^{\text {st }}$ ) and the profit and loss sharing ratio between the customer and the bank is $57 \%: 43 \%$. If the profit earned by the bank for one month deposit at December 31 amounts to $\mathrm{Rp} 20.000 .000$ and the average period of 1 month deposit is $\mathrm{Rp}$ 950.000.000, how much profit does A obtain?

Calculation:

$\frac{10.000 .000}{950.000 .000} \times 20.000 .000 \times 57 \%=\operatorname{Rp} 120.000$

(before tax deduction)

Thus, there are elements of uncertainty in the benefit obtained by a customer of mudharabah deposit, because how much money of real income to be received by the customer is largely dependent on the revenue of the sharia bank. The size of profit and loss sharing obtained by the owners of mudharabah savings and deposits rely on the revenue of sharia banks, profit and loss sharing ratio between the bank and its customers, the nominal of deposit, the average balance of deposit for a certain period in sharia bank, and term of deposit due to an effect given by the length of investment. ${ }^{17}$

Based on the examples of funds collection agreements as outlined in mudharabah agreements, profit and loss sharing has not been fully implemented because it only contains a provision to share the profits, while the loss is not listed in the mudharabah deposit agreements in $\mathrm{Y}$ sharia bank, contrary to the X sharia bank which already includes them both, fulfilling the characteristic of PLS or revenue sharing. Similarly, the profit and loss sharing system that is used - whether to use revenue sharing or profit sharing in all the agreements in the researched sharia banks - is not included in the agreement, thus the investing customers do not know what system is used in dividing profits. This is clearly contrary to the DSN Fatwa Number 15/DSN-MUI/IX/2000 which clearly determines that the establishment of the principle of revenue sharing of selected business should be agreed in the document.

\section{The Application of Principle of Justice in Financing Based on Profit and Loss}

\footnotetext{
Muslimin H. Kara, 2005, Bank Syariah di Indonesia: Analisis Kebijakan Pemerintah Indonesia tentang Perbankan Syariah, UII Press, Yogyakarta, p. 72. 


\section{Sharing}

Financing to be studied in this research is the one based on the mudharabah and musharakah contract. There are similarities and differences between mudharabah and musharakah, which are as follows: ${ }^{18}$

In a regular loan, the borrower (debtor) will provide to a lender (creditor) a definite sum of profit

Table 1. Comparison Between Mudharabah and Musharakah

\begin{tabular}{|c|c|c|}
\hline Remarks & Mudharabah & Musharakah \\
\hline Underlying principle & $\begin{array}{l}\text { Financing is based on profit and loss sharing } \\
\text { principle. }\end{array}$ & $\begin{array}{l}\text { Financing is based on profit and } \\
\text { loss sharing principle. }\end{array}$ \\
\hline Capital type & Cash. & $\begin{array}{l}\text { Cash and property assessable by } \\
\text { money. }\end{array}$ \\
\hline Capital participation & $\begin{array}{l}\text { Only the owners of capital (shahibul maal) } \\
\text { submit their capital to the fund manager } \\
\text { (mudharib). With the capital, the manager } \\
\text { (mudharib) will conduct activities to } \\
\text { manage the capital. }\end{array}$ & $\begin{array}{l}\text { Each party deposits the capital, } \\
\text { and the business is carried out } \\
\text { together. }\end{array}$ \\
\hline Profit & $\begin{array}{l}\text { Such profit is shared based on agreement } \\
\text { (profit and loss sharing). }\end{array}$ & $\begin{array}{l}\text { The profit-sharing is based on } \\
\text { the mutually agreed percentage. }\end{array}$ \\
\hline Loss & $\begin{array}{l}\text { Any losses will be borne by the owners } \\
\text { of capital (shahibul maal), given that } \\
\text { the loss is not due to deliberate action of } \\
\text { the fund manager (mudharib), while the } \\
\text { fund manager suffers from loss of time, } \\
\text { energy and mind. If the loss caused by the } \\
\text { negligence of the fund manager (mudharib), } \\
\text { the fund manager must bear the loss. }\end{array}$ & $\begin{array}{l}\text { In the event of loss, it is borne } \\
\text { jointly in accordance with the } \\
\text { amount of capital each party has }\end{array}$ \\
\hline
\end{tabular}

Source: Adapted from various sources of reference, namely Karim Adiwarwaman 2007, Bank Islam: Fiqh and Financial Analysis, King Grafindo Persada, Jakarta. See also Muhammad Syafii Antonio, 2000, The Islamic Bank: An Introduction to General, Tazkia Institute, DSN on Mudharabah and Musharakah, Jakarta.

regardless of the results of business of the debtor. It would do them a lot more justice if both parties share the profits and losses. Justice in this context has two dimensions: the investor is entitled to get the profit, but it should be well worth the risk and effort required, and thus determined by the profit from the funded project. Therefore, the one forbidden in Islam is a predetermined profit amount, and the determined number in profit and loss sharing is only the profit sharing ratio, not the fixed rate of profit. ${ }^{19}$

Financings based on profit and loss sharing in various sharia banks ${ }^{20}$ are generally not the same in applying their methods. Musharakah financing is widely implemented depending on the role of managing partner in the business project, and capital contribution is provided by both parties, which are the sharia bank and the customer. If at the end of the musharakah agreement it turns out that there is a loss not due to negligence, mismanagement, or breach of the provisions of the agreement, if any, shall be divided between the two parties according to the percentage of the amount of capital that is included in the agreement. Conversely, if the loss is caused by negligence, mismanagement, or breach

\footnotetext{
18 Adapted from various sources of reference, which are: Adiwarwaman Karim, 2007, Bank Islam: Analisis Fiqih dan Keuangan, Raja Grafindo Persada, Jakarta. Lihat juga Muhammad Syafii Antonio, 2000, Bank Syariah: Suatu Pengenalan Umum, Tazkia Institute, DSN Fatwa Regarding Mudharabah and Musharakah, Jakarta.

19 Latifa M. Algaoud and Mervyn K. Lewis, Op.cit., p. 64.

20 According to Abdullah Saeed in Jordan Islamic Bank (JIB), Faisal Islamic of Egypt (FIBE) and Tadamon Islamic Bank of Sudan, Op.cit., pp. $122-123$.
} 
of the provisions of the contract, then the partner should be responsible for all the losses. ${ }^{21}$

The above conditions also apply to $\mathrm{X}$ and $\mathrm{Y}$ sharia banks in channeling the funds through musharakah agreement. The contribution of capital is derived from sharia banks and customers, but capital management is only done by the customer. Sharia banks only conduct surveillance, while monitoring of capital management is also done by the customer. Even in musharakah financing, collateral is guaranteed to secure the capital that has been provided by sharia banks when customers are in default. In fact, sharia banks cannot simply distribute funds to mudharib, either in the form of mudharabah or musharakah only on the basis of trust, because there is always a risk in the financing has been given to mudharib, namely the failure of financing that can occur due to several factors, such as side-streaming of financing funds by mudharib. To reduce the likelihood of risk, sharia banks can set a number of certain limitations when channeling funds to mudharib. In principle, in mudharabah, shahibul maal does not set certain conditions to mudharib. However, if deemed necessary, shahibul maal may set boundaries in order to save its capital from loss. If mudharib violates these limits, then mudharib should be responsible in case of losses. ${ }^{22}$ Given the limitations and conditions laid down, in providing funds to its customers, sharia banks are expected to avoid things that could harm both parties, who will carry out their rights and obligations with great caution.

A good agreement is part of risk management, because any agreement that has been agreed will always have potential risks that may occur in the future. Therefore, the step to minimize potential losses, among others, is by being careful in analyzing the reputation, the legal capacity, and financial capacity of prospective customers. Agreement as a legal contract must meet the elements that can be classified into three groups, namely essentialia element, naturalia element, and accidentalia element. ${ }^{23}$ Similarly, in agreements at sharia banks, agreement format contains the minimum elements that must be fulfilled. Pursuant to Article 38(1) of Law Number 30 of 2004 regarding Notary (UUJN), the agreement between the sharia bank and the customer is made based on the right anatomical arrangement or contract pattern, consisting of (a) agreement opening or head; (b) agreement body; (c) agreement end or closing. According to Ascarya, the minimum requirements in musharakah and mudharabah financing agreements adopted by sharia banking are as follows: ${ }^{24}$

The principle of justice is reflected in the clauses contained in the mudharabah and

Table 2. Minimum Requirements in Mudharabah and Musharakah Agreements

\begin{tabular}{|c|c|c|c|}
\hline No. & Anatomy & Mudharabah & Musharakah \\
\hline 1. & $\begin{array}{l}\text { Agreement } \\
\text { opening or head }\end{array}$ & $\begin{array}{l}\text { Uses the word mudharabah. } \\
\text { Mentions the day and date of agreement. }\end{array}$ & $\begin{array}{l}\text { Uses the word musharakah. } \\
\text { Mentions the day and date of } \\
\text { agreement. }\end{array}$ \\
\hline 2. & Agreen & $\begin{array}{l}\text { Contains the definition to equate both } \\
\text { parties to the interpretative technical } \\
\text { terminology. } \\
\text { States the parties to the transaction and/ } \\
\text { or their representatives. } \\
\text { Establishes the bank as the owner of the } \\
\text { funds or shahibul maal and customers } \\
\text { as a fund manager or mudharib. }\end{array}$ & $\begin{array}{l}\text { Contains the definition to equate } \\
\text { both parties to the interpretative } \\
\text { technical terminology. } \\
\text { States the parties to the transaction } \\
\text { and/or their representatives. } \\
\text { Establishes the bank and customer } \\
\text { as partners or syarik. }\end{array}$ \\
\hline
\end{tabular}

Ibid., p. 124

Adiwarman A. Karim, 2007, Bank Islam: Analisis Fiqih dan Keuangan, Raja Grafindo Persada, Jakarta, p. 212.

Ricardo Simanjuntak, 2006, Teknik Perancangan Kontrak Bisnis, Mingguan dan Bisnis Kontan, Gramedia, Jakarta, p. 91.

Ascarya, 2007, Akad dan Produk Bank Syariah, Raja Grafindo Persada, Jakarta, p. 59 
Includes an agreed profit and loss sharing ratio for each party.

Specifies the type of business that will be done by the customer.

Mentions that the losses are incurred by the bank if they are not caused by agreement violation and acts beyond capacity.

Establishes penalties for negligence if the customer fails to pay profit and loss sharing in time.

Establishes an agreement in the event of force majeure.

Establishes a guarantee from a third party if necessary.

Establishes sanctions if necessary.

Establishes Sharia Arbitration or religious court or state court as a settlement in the event of dispute.
Establishes the contribution of fund given by each party for the business.

Includes an agreed profit sharing ratio for each party.

Includes the portion of the loss charged in proportion to the contribution of each party's fund.

Specifies the type of business that will be done by the customer.

Establishes penalties for negligence if the customer fails to pay profit and loss sharing in time. Establishes an agreement in the event of force majeure.

Establishes a guarantee from a third party if necessary.

Establishes sanctions if necessary. Establishes Sharia Arbitration or religious court or state court as a settlement in the event of dispute.

3. Agreement end or Signatures of parties. closing. Agreement witnesses.

Agreement witnesses.

Source: Based on the processing of clauses in exemplary mudharabah and musharakah agreements from $\mathrm{X}$ and $\mathrm{Y}$ Sharia Banks.

musharakah agreements, based on the analysis of The principle of justice in mudharabah and both contracts in $\mathrm{X}$ and $\mathrm{Y}$ sharia banks, it can be musharakah agreements both in $\mathrm{X}$ and $\mathrm{Y}$ Sharia summarized as follows:

Table 3. Comparison of Musharakah and Mudharabah in X Sharia Bank and Y Sharia Bank

\begin{tabular}{|c|c|c|}
\hline Remarks & X Sharia Bank & Y Sharia Bank \\
\hline \multirow[t]{7}{*}{ Mudharabah } & $\begin{array}{l}\text { Contains the clause on mudharabah } \\
\text { agreement that is an agreement between } \\
\text { the bank as shahibul maal and customer as } \\
\text { mudharib. }\end{array}$ & $\begin{array}{l}\text { Contains the clause on mudharabah } \\
\text { agreement that is an agreement between } \\
\text { the bank as shahibul maal and customer } \\
\text { as mudharib. }\end{array}$ \\
\hline & $\begin{array}{l}\text { Contains the clause stating that the losses } \\
\text { are borne by the bank unless such losses } \\
\text { are caused by negligence of customer. }\end{array}$ & $\begin{array}{l}\text { Contains the clause stating that the losses } \\
\text { are borne by the bank unless such losses } \\
\text { are caused by negligence of customer. }\end{array}$ \\
\hline & $\begin{array}{l}\text { Contains the agreement of profit and loss } \\
\text { sharing portion and establishes the used } \\
\text { pattern in determining profit division } \\
\text { (revenue sharing or profit sharing). }\end{array}$ & $\begin{array}{l}\text { Contains the agreement of profit and } \\
\text { loss sharing portion and but does no } \\
\text { establish the used pattern in determining } \\
\text { profit division (revenue sharing or profi } \\
\text { sharing). }\end{array}$ \\
\hline & $\begin{array}{l}\text { Does not use the term "debt" in the } \\
\text { agreement, if paid off earlier then customer } \\
\text { is still obliged to share profits with the } \\
\text { bank. }\end{array}$ & $\begin{array}{l}\text { Uses the term "debt" in the agreement, } \\
\text { if paid off earlier then customer is still } \\
\text { obliged to share profits with the bank. }\end{array}$ \\
\hline & $\begin{array}{l}\text { There is a sanction for lateness, but such } \\
\text { sanction fee goes to social funding account. }\end{array}$ & $\begin{array}{l}\text { Does not mention about sanction fee in } \\
\text { profit and loss sharing payment. }\end{array}$ \\
\hline & Contains a clause regarding collateral. & Contains a clause regarding guarantee. \\
\hline & $\begin{array}{l}\text { Contains a clause regarding prudence } \\
\text { principle: customer statement and } \\
\text { guarantee, limitation of customer activities, } \\
\text { insurance, surveillance and inspection. }\end{array}$ & $\begin{array}{l}\text { Contains a clause regarding prudence } \\
\text { principle: customer statement and } \\
\text { acknowledgement, violations, insurance, } \\
\text { surveillance and inspection. }\end{array}$ \\
\hline
\end{tabular}


In force majeure clause, there is no explanation of the consequence of

"[...] delay or failure of a Party to notify the existence of the force majeure will result in non-recognition of the event as force majeure by the other Party".
In the force majeure clause, it is confirmed that "if within 30 (thirty) calendar days after such notice the condition has not expired or CUSTOMER and Shohibul Maal have not reached an agreement to amend this Agreement in order to be able to continue Financing Facility, the Financing Facility is finished and all Financing Facility following the earnings of Shohibul Maal immediately become due and shall be returned by the CUSTOMER in accordance with the Payment Schedule".

The closing clause has reflected the protection principle as set out in the Consumer Protection Act because any changes in the agreement will be deliberated first.

The closing clause has reflected the protection principle as set out in the Consumer Protection Act because any changes in the agreement will be deliberated first.

\begin{tabular}{ll}
\hline Remarks & X Sharia Bank \\
\hline Musharakah & $\begin{array}{l}\text { There is a clause which contains capital } \\
\text { contributions from bank and customer, as } \\
\text { outlined in percentage. }\end{array}$ \\
\cline { 2 - 2 } & $\begin{array}{l}\text { There is a stated pattern used in determining } \\
\text { profit division, between revenue sharing } \\
\text { and profit sharing. }\end{array}$ \\
\cline { 2 - 2 } & $\begin{array}{l}\text { There is a clause explaining the losses } \\
\text { borne proportionally between the bank and } \\
\text { customer in accordance with each capital } \\
\text { portion. }\end{array}$
\end{tabular}

Y Sharia Bank

There is no clause containing capital contribution from customer, but only the bank.

There is no stated pattern used in determining profit division, between revenue sharing and profit sharing.

There is no clause explaining the losses borne proportionally between the bank and customer in accordance with each capital portion, but only contains a clause stating that losses are borne by the bank unless such losses are caused by the customer's negligence, whereas the character of musharakah is profit and loss sharing between the syariks.

\begin{tabular}{|c|c|}
\hline Contains a clause regarding collateral. & Contains a clause regarding guarantee. \\
\hline $\begin{array}{l}\text { There is a sanction fee for lateness, but } \\
\text { such fee goes to social funding account. }\end{array}$ & $\begin{array}{l}\text { There is no such clause regarding lateness } \\
\text { in paying profit and loss sharing. }\end{array}$ \\
\hline $\begin{array}{l}\text { Contains a clause regarding prudence } \\
\text { principle: customer statement and } \\
\text { guarantee, limitation of customer activities, } \\
\text { insurance, and surveillance and inspection. }\end{array}$ & $\begin{array}{l}\text { Contains a clause regarding prudence } \\
\text { principle: customer statement and } \\
\text { acknowledgement, violations, insurance, } \\
\text { surveillance and inspection. }\end{array}$ \\
\hline $\begin{array}{l}\text { In force majeure clause, there is no } \\
\text { explanation of the consequence of } \\
\text { "[...] delay or failure of a Party to notify } \\
\text { the existence of the force majeure will } \\
\text { result in non-recognition of the event as } \\
\text { force majeure by the other Party". }\end{array}$ & $\begin{array}{l}\text { In the force majeure clause, it is confirmed } \\
\text { that "if within } 30 \text { (thirty) calendar days } \\
\text { after such notice the condition has not } \\
\text { expired or CUSTOMER and Shohibul } \\
\text { Maal have not reached an agreement } \\
\text { to amend this Agreement in order to } \\
\text { be able to continue Financing Facility, } \\
\text { the Financing Facility is finished and } \\
\text { all Financing Facility following the } \\
\text { earnings of Shohibul Maal immediately } \\
\text { become due and shall be returned by } \\
\text { the CUSTOMER in accordance with the } \\
\text { Payment Schedule". }\end{array}$ \\
\hline
\end{tabular}


The closing clause has reflected the protection principle as set out in the Consumer Protection Act because any changes in the agreement will be deliberated first.
The closing clause has reflected the protection principle as set out in the Consumer Protection Act because any changes in the agreement will be deliberated first.

Source: Based on the processing of clauses in exemplary mudharabah and musharakah agreements from $\mathrm{X}$ and $\mathrm{Y}$ Sharia Banks.

Banks has been reflected in their agreement clauses, although there is still a clause lacking of reflecting justice, namely in the clause:

a) About payment, that "if the customer pay back or pay off debt facilitated by the bank earlier than the agreed time, then it does not mean that the payment will eliminate or reduce the portion of revenue/profits that belong to the bank as stipulated in the agreement". ${ }^{25}$ This clause does not reflect the principles of justice and the character of financing based on the principle of profit and loss sharing. If such financing has been repaid, the bank should not be allowed to claim a part of the profits obtained when the funds are managed by mudharib. However, the sharia bank argues that the funds are used in the distribution of funds is mostly depositors' funds, that sharia bank provides the investing customers their portion of the profit and loss sharing on the management of all customer funds, so that if the distribution of funds does not give profits, there would be no profits to be distributed to the investing customers.

b) The use of the term "debt" in mudharabah agreement in Y Sharia Bank which should not be done, given the agreement's character is profit and loss sharing, not accounts payable. However, the sharia bank argues that the funds collected are recorded as liabilities in the balance sheet, as well as the distribution of funds in the balance sheet are also recorded as debt. Therefore, the funds used for financing are the depositors' fund, so the financed customers are obliged to return the capital they receive in accordance with the predetermined time period.

\section{Conclusion}

In fund collections through mudharabah agreements, profit and loss sharing system as a whole has not been implemented because the agreement only contains sharing profits alone, not containing provisions on loss sharing. If any damage occurs, the rights of shahibul maal will be borne by Sharia Financial Institution. The agreement does not mention the used sharing system used, whether it is the profit sharing or revenue sharing. On the contrary, the mudharabah and musharakah financing agreements already include a clause about sharing both profits and losses. The principle of justice in mudharabah and musharakah financing agreements both in $\mathrm{X}$ and $\mathrm{Y}$ Sharia Banks has been reflected in their agreement clauses, although there are still some clauses lacking of reflecting justice, namely the clause on payment and the use of the term "debt" in Y Sharia Bank that should not be done in mudharabah agreement, given the agreement's character is profit and loss sharing, not accounts payable. 


\section{REFERENCES}

A. Books

Anshori, Abdul Ghofur, 2006, Filsafat Hukum Gadjah Mada University Press, Yogyakarta. , 2006, Pokok-Pokok Hukum

Perjanjian Islam di Indonesia, Citra Media, Yogyakarta.

Ascarya, 2007, Akad dan Produk Bank Syariah, Raja Grafindo Persada, Jakarta.

Antonio, Muhammad Syafii, 2000, Bank Syariah: Suatu Pengenalan Umum, Tazkia Institute, Jakarta.

Elgar, Edward, Mervyn Lewis and Latifa Algaoud, 2001, Perbankan Syariah (Trans. Burhan Wirasubrata), Serambi Ilmu Semesta, Jakarta.

Hadjon, Philipus M. and Tatiek Sri Djatmiati, 2005, Argumentasi Hukum, Gadjah Mada University Press, Yogyakarta.

Kara, Muslimin H., 2005, Bank Syariah di Indonesia: Analisis Kebijakan Pemerintah Indonesia tentang Perbankan Syariah, UII Press, Yogyakarta.

Karim, Adiwarwaman, 2007, Bank Islam: Analisis Fiqih dan Keuangan, Raja Grafindo Persada, Jakarta.

Manan, Abdul, 2006, Reformasi Hukum Islam di Indonesia, Raja Grafindo Persada, Jakarta.

Muhamad, 2005, Manajemen Pembiayaan Bank Syariah, Unit Penerbit dan Percetakan (UPP)
AMP YKPN, Yogyakarta.

Saeed, Abdullah, 1996, Islamic Banking and Interest a Study of The Prohibition of Riba and Contemporary Interpretation, E.J Briil, Leiden-New York-Koln.

Simanjuntak, Ricardo, 2006, Teknik Perancangan Kontrak Bisnis, Mingguan dan Bisnis Kontan, Gramedia, Jakarta.

\section{B. Articles of Journal}

Shomad, Abd., "Akad Mudharabah dalam Perbankan Syariah", Yuridika, Vol. 16, No. 4, July-August 2001.

\section{Internet Articles}

Agustianto, "Prinsip Syariah dalam Ekonomi dan Perbankan", http://www.agustiantocentre. $\mathrm{com} / ? p=345$, accessed on June $21^{\text {st }} 2013$.

Bank Indonesia, "Financing Data from Sharia Banking Statistic", http://www.bi.go.id, accessed on May $28^{\text {th }} 2013$.

\section{Regulations}

Bank Indonesia Regulation Nomor 8/21/PBI/2006 dated October $5^{\text {th }} 2006$ regarding Asset Quality Rating for Commercial Banks Conducting Business Based on Sharia Principles. 